\title{
Solid tissue culture for cytogenetic analysis: a collaborative survey for the Association of Clinical Cytogeneticists
}

\author{
C S Rodgers, M R Creasy, M Fitchett, C T Maliszewska, N R Pratt, J J Waters
}

\begin{abstract}
Aims-To survey the diagnostic service provided by UK laboratories for the culture of solid tissue samples (excluding tumours) and in particular to examine the variation in culture success rates and the problems of maternal cell overgrowth. Methods-Twenty seven laboratories took part in a collaborative survey during 1992. Each laboratory submitted data on up to a maximum of 60 consecutive specimens (n = 1361) over a six month period.

Results-Skin specimens, the largest category received $(n=520)$, were the most problematic (51\% success rate). Culture success rates were significantly lower $(43 \%)$ when skin specimens $(n=140)$ were transported dry to the laboratory. Success rates for skin specimens also varied, depending on the origin of the specimen, from $18 \%$ for intra-uterine deaths (IUD) $(n=94)$ to $85 \%$ for neonatal deaths $(n=33)$ and $83 \%$ for live patients $(n=54)$. Culture of selected extra-fetal tissues from IUD, stillbirths and following elective termination of pregnancy (TOP) gave comparable success rates to those achieved for skin samples from neonatal deaths and live births. Skewed sex ratios, female > male, were identified for products of conception (POC) $(n=298)$ and placental biopsy specimens $(n=97)$.

Conclusions-By appropriate selection, transport and processing of tissues, and in particular by avoiding relying solely on skin samples from IUD, stillbirths and TOP, an increase in culture success rates for solid tissue samples submitted for cytogenetic analysis could be achieved. The high risk of maternal cell contamination from POC and placental biopsy specimens was also identified in this survey.

( Clin Pathol 1996;49:638-641)
\end{abstract}

Keywords: solid tissue, cell culture, cytogenetics.

A number of studies have shown that cytogenetic investigation makes a significant contribution to fetal pathology. ${ }^{1-3}$ About $40 \%$ of spontaneous abortions have a chromosome abnormality. ${ }^{4}$ For stillbirths and neonatal deaths, where the cause of death is unknown, the frequency of chromosome abnormalities is approximately $7 \% .^{5}$ For fetuses ( $>28$ weeks) with multiple malformations, however, the observed rate of chromosome abnormality is $\triangle$ approximately $50 \%{ }^{5}$ Thus, particularly in this is category, the results from chromosomal studies $\vec{\circ}$ may be informative and permit diagnosis of fetal abnormality, as well as providing infor- $\vec{\omega}$ mation for recurrence risks in future pregnan- $\frac{\overrightarrow{0}}{\mathrm{O}}$ cies. Cytogenetic investigation of fibroblasts from skin biopsy specimens may be valuable ${ }_{\infty}^{+}$ from subjects with known or suspected chromosome mosaicism. In addition, culture of ${ }_{\infty}^{\omega}$ skin biopsy specimens may also be required $\bigcirc$ from individuals with suspected inborn errors of metabolism for biochemical investigation. UK NEQAS (UK National External Qualitye Assessment Scheme) data for the most recently $\stackrel{\text { s }}{-}$ available period, 1993/1994, revealed that over $\vec{\theta}$ 8300 solid tissue samples were submitted to $\%$ cytogenetic laboratories for culture, ${ }^{6}$ indicating that there was clearly a demand for this diagnostic service.

The data for solid tissue samples (for example, fetal and extra-fetal tissues, and neonatal $\stackrel{\odot}{\circ}$ tissue and postnatal skin biopsy specimens, but $\vec{\overrightarrow{ }}$ excluding tumours) collected by UK NEQAS 3 since 1982 showed that the overall success rate for this type of sample is consistently below that of other cultured samples-that is, chorionic villus and amniotic fluid samples. The overall average success rate for solid tissue cul- 3 . tures has remained at around $65 \%$ (success 8 rates varied between 35 and $85 \%$ for individual $₹$ laboratories). This compared with a figure of $\bigcirc$ $98 \%$ for chorionic villus and amniotic fluid samples over the same period. To try to identify the reasons for the relatively low solid tissue ${ }_{0}$ culture success rates, the Scientific Committee of the Association of Clinical Cytogeneticists (ACC) commissioned a study ${ }^{7}$ to determine $\omega$ which factors could be important in delivering? an effective service. It should be emphasised $\stackrel{\circ}{\subset}$ that the survey did not attempt to evaluate the $\stackrel{\infty}{\mathscr{D}}$ overall clinical value of the service provided. This issue has been reviewed elsewhere. ${ }^{89}$

\section{Methods}

Thirty three UK laboratories, which were known to be providing a diagnostic service, $\frac{\delta}{0}$ were invited to take part in a survey of solid tissues processed for cytogenetic analysis. Twenty seven $(82 \%)$ agreed to submit data. Participating laboratories returned a detailed questionnaire which investigated laboratory policy and took part in a prospective study of culture methods, using a standard proforma, over a period of six months during 1992 (maximum of 60 samples per laboratory). A total of 1361 
Table 1 Classification of origin of specimens and specimens received

\begin{tabular}{ll}
\hline Origin of specimen & Specimen received \\
\hline $\begin{array}{l}\text { Spontaneous abortion }(<28 \\
\text { weeks) }\end{array}$ & Products of conception \\
$\begin{array}{l}\text { Termination of pregnancy } \\
\text { Intra-uterine death }\end{array}$ & $\begin{array}{l}\text { Fetus } \pm \text { placenta } \\
\text { Stillbirth ( }>28 \text { weeks) }\end{array}$ \\
$\begin{array}{l}\text { Neonatal death } \\
\text { Placental biopsy specimen }\end{array}$ \\
Live patient & $\begin{array}{l}\text { Skin sample/skin biopsy } \\
\text { specimen }\end{array}$ \\
\hline
\end{tabular}

samples was submitted for evaluation. It was this prospective survey that provided the data presented herein.

In order to ensure that the survey had a consistent approach, the origin of the specimens was coded into functional but overlapping categories. The categories of origin chosen for the survey and defined by the proforma are given in table 1 , as are the categories of specimens chosen for the survey. Terminations of pregnancy (TOP) were coded separately because of the importance of this group of specimens for follow up of prenatal diagnosis. Intra-uterine death (IUD) is a common cause for referral of samples for cytogenetic analysis, and, anecdotally, is associated with a high failure rate, and so was coded separately from spontaneous abortion. Neither category was defined precisely, relying on individual laboratory categorisation rather than precise clinical definition.

\section{Results}

The results presented in this survey are based on 1361 processed specimens entered from 27 laboratories. On average, 50 samples were entered per laboratory (range 26-60). The survey data represented a reasonable proportion of the total UK workload for this class of specimen submitted to UK NEQAS for 1992 ( $\mathrm{n}=$ 7289).

\section{SPECIMEN ORIGIN}

Success rates for specimens received ( $\mathrm{n}=$ 1257) from different categories of origin are shown in table 2 . Success rates varied widely from $41 \%$ for IUD to $87 \%$ for neonatal death. Abnormality rates also varied considerably and were consistent with larger surveys. ${ }^{10}$ The highest abnormality rate was $48 \%$ for TOP samples, a highly selected group, the majority of which arose as a result of prenatal diagnosis of chromosome abnormality or fetal abnormality detected on ultrasound scan. Breakdown of

Table 2 Origin of specimens

\begin{tabular}{lclc}
\hline $\begin{array}{l}\text { Origin of specimen } \\
\text { Spontaneous }\end{array}$ & Number received & Number successful (\%) & Number abnormal (\%)* \\
$\quad$ abortion & 404 & $286(71)$ & $80(28)$ \\
TOP & 334 & $211(63)$ & $102(48)$ \\
IUD & 120 & $52(43)$ & $19(21)$ (all cases) \\
$\quad<28$ weeks & 94 & $35(37)$ & - \\
$>28$ weeks & 155 & $88(57)$ & $8(9)$ \\
Stillbirth & 52 & $45(87)$ & $16(36)$ \\
Neonatal death & 91 & $73(80)$ & $21(29)$ \\
Live patient & 104 & ND & ND \\
Others/not given & 1361 & $793(63) \dagger$ & $246(24) \dagger$ \\
Total &
\end{tabular}

^As a percentage of successful samples.

†Data exclude others/not given category $(n=104)$.
Table 3 Specimens received

\begin{tabular}{lcl}
\hline Specimen type & $\begin{array}{l}\text { Number } \\
\text { received }\end{array}$ & $\begin{array}{l}\text { Number } \\
\text { successful (\%) }\end{array}$ \\
\hline POC & 298 & $236(79)$ \\
Fetus \pm placenta & 171 & $114(66)$ \\
Placental biopsy specimen & 165 & $119(72)$ \\
Placental membrane/cord & 49 & $32(65)$ \\
Skin & 520 & $263(51)$ \\
Others & 158 & ND \\
Total & 1361 & $767(64)^{\star}$ \\
\hline
\end{tabular}

*Data exclude others category $(n=158)$.

IUD specimens into gestational age groups ( $<28$ weeks; $>28$ weeks) revealed lower success rates compared with other specimens within the same gestational age group.

\section{TRANSPORT OF SAMPLES}

Samples taken for cytogenetic analysis were received in sterile containers either dry, or in physiological saline or in medium (often supplied by the cytogenetics laboratory). This information, when available, was collected for each of the survey samples. A breakdown of culture success rates for the three largest categories of specimen: skin $(n=476)$, products of conception (POC) $(n=266)$ and fetus with or without placenta $(n=162)$, where the method of transport to the laboratory was known, indicated that skin biopsy specimens had a significant lower success rate when specimens were transported dry (43\%) compared with those in saline $(59 \%)(p<0.01)$ and in medium (58\%) ( $\mathrm{p}<0.001)$, presumably due to the fact that small skin biopsy samples were liable to dry out rapidly.

SPECIMENS RECEIVED

A breakdown of the main categories of specimen received $(n=1203)$ is given in table 3 . Skin specimens showed a lower culture success rate $(51 \%)$ than other specimens (65$79 \%)$. Given that the skin samples were the largest single category of specimen entered into the audit $(n=520)$, this category of specimen was investigated further.

A breakdown of the skin specimens received by origin $(n=511)$ is shown in table 4 . The wide variation in culture success rate (18$85 \%$ ) indicated that the origin of the specimen is a critical factor in the culture success rate for these specimens.

TISSUES CULTURED

Data for tissue culture success rates for samples from IUD, TOP and stillbirths are compared in table 5. With the exception of the category "other fetal tissues" from IUD they all gave better results than skin samples.

\section{MATERNAL CELL CONTAMINATION}

The sex ratio of normal results were compared for the three largest classes of specimen received to assess the extent of maternal cell overgrowth (table 6). For POC specimens, and to a lesser extent for placental biopsy specimens, there was a significant skew in favour of normal female results $(46, \mathrm{XX})$, indicating that maternal cell contamination and subsequent maternal cell overgrowth frequently occurs. Skewing of the sex ratio occurred for POC 
Table 4 Skin specimens received by origin

\begin{tabular}{lcclc}
\hline & $\begin{array}{l}\text { Number } \\
\text { received }\end{array}$ & $\begin{array}{l}\text { Per cent of total } \\
\text { specimens received }\end{array}$ & $\begin{array}{l}\text { Number successful } \\
\text { (skin } \\
\text { samples) }\end{array}$ & $\begin{array}{l}\text { Per cent successful } \\
\text { (all tissues) }\end{array}$ \\
\hline Spontaneous abortion & 107 & 26 & $54(50)$ & 71 \\
TOP & 162 & 49 & $93(57)$ & 63 \\
IUD & 94 & 43 & $17(18)$ & 41 \\
Stillbirth & 61 & 39 & $17(28)$ & 57 \\
Neonatal death & 33 & 63 & $28(85)$ & 87 \\
Live patient (skin biopsy) & 54 & 100 & $45(83)$ & 83 \\
Not given & 9 & ND & ND & ND \\
Total & 520 & 38 & $254(50)$ & $63^{\star}$ \\
\hline
\end{tabular}

*Taken from table 2.

Table 5 Tissue culture success rates (\%) by origin of specimen (IUD, TOP or stillbirth). Numbers of samples are given in parentheses

\begin{tabular}{llcl}
\hline $\begin{array}{l}\text { Origin of } \\
\text { specimen }\end{array}$ & Skin sample & $\begin{array}{l}\text { Other fetal } \\
\text { tissue }\end{array}$ & $\begin{array}{l}\text { Extra-fetal } \\
\text { tissue }\end{array}$ \\
\hline IUD & $16 \%(104)$ & $7 \%(15)$ & $71 \%(63)$ \\
TOP & $57 \%(162)$ & $76 \%(34)$ & $81 \%(56)$ \\
Stillbirth & $28 \%(61)$ & $100 \%(6)$ & $80 \%(60)$ \\
\hline
\end{tabular}

whichever tissue was identified as being cultured (table 7). This phenomenon was highlighted further by comparing the proportion of cases with an abnormal karyotype where presumptive maternal cells were also detected for different categories of specimen received. POC specimens showed that approximately one quarter of abnormal cases had a presumptive maternal cell population present (table 8).

\section{Discussion}

The survey had a number of limitations. A proportion of the data was incomplete, with not all data for each specimen submitted. The available data from such specimens were included in the survey. Categories of specimen origin and the categories of specimen received were defined by the proforma. Category overlaps in terms of specimen origin-for example, IUD/spontaneous abortion and IUD/ TOP, were present. Part of the remit of the survey was to identify the reason for the low success rate for tissues cultured from IUD specimens. For this reason, data from such specimens were specifically requested and entered in the survey under the category of IUD. The data have been broken down into two groups, IUD $<28$ weeks and IUD $>28$ weeks to be comparable with the spontaneous abortion and stillbirth categories, respectively. The survey was initiated when the definition of a spontaneous abortion was defined as a miscarriage at less than 28 weeks. Some difficulty in interpretation of the data occurred with the categories of specimen received. In retrospect it could be seen that the category of

Table 6 Maternal cell contamination: sex ratios from specimens with a normal cytogenetic result

\begin{tabular}{lllc}
\hline & $\begin{array}{l}\text { Female }(46, X X) / \\
\text { male }(46, X Y)\end{array}$ & Sex ratio & Difference from 1:1 \\
\hline POC & $120 / 30$ & 4.0 & $\mathrm{p}<0.001$ \\
Fetus \pm placenta & $27 / 43$ & 0.6 & $\mathrm{NS}$ \\
Placental biopsy specimen & $58 / 39$ & 1.5 & $\mathrm{p}<0.01$ \\
Placental membrane/cord & $11 / 11$ & 1.0 & ND \\
Skin & $89 / 100$ & 0.9 & NS \\
\hline
\end{tabular}

Table 7 Maternal cell contamination in POCs: sex ratios from specimens with a normal cytogenetic result by tissue cultured

\begin{tabular}{lcl}
\hline Tissue cultured & $\begin{array}{l}\text { Female }(46, X X) / \\
\text { male }(46, X Y)\end{array}$ & $\begin{array}{l}\text { Sex } \\
\text { ratio }\end{array}$ \\
\hline POC & $38 / 6$ & 6.3 \\
Placenta & $9 / 5$ & 1.8 \\
Villi & $28 / 13$ & 2.1 \\
Membrane & $19 / 2$ & 9.5 \\
Skin & $8 / 3$ & 2.7 \\
Fetal tissue & $4 / 1$ & 4.0 \\
No fetal tissue & $8 / 0$ & ND \\
Other (n=8) & ND & ND \\
\hline
\end{tabular}

Table 8 Abnormal cytogenetic result with presumptive maternal cell contamination $(46, X X)$

\begin{tabular}{|c|c|c|c|}
\hline Specimen received & $\begin{array}{l}\text { Number } \\
\text { abnormal } \\
\text { (with 46,XX) }\end{array}$ & $\begin{array}{l}\text { Total } \\
\text { number } \\
\text { abnormal }\end{array}$ & $\begin{array}{l}\text { Per cent } \\
\text { abnormal } \\
\text { (with 46,XX }\end{array}$ \\
\hline POC & 20 & 82 & 24 \\
\hline Fetus \pm placenta & 4 & 49 & 8 \\
\hline $\begin{array}{l}\text { Placental biopsy } \\
\text { specimen }\end{array}$ & 5 & 28 & 18 \\
\hline Skin & 6 & 51 & 12 \\
\hline
\end{tabular}

fetus plus or minus $( \pm)$ placenta was too loosely defined. As a result it was not possible to determine whether extra-fetal tissues hado not been cultured for reasons of policy orọ because extra-fetal tissue was not available.

Despite its limitations, the survey did\& identify the poor culture success rates of the largest category of specimens received, skin samples, and ways in which success rates could be improved. This category included biopsy@ specimens taken from living patients andळ immediate postmortem samples which grew in $\vec{\Rightarrow}$ about $80 \%$ of cases. Use of an appropriate medium for transport of specimens rather than sending them dry could improve success rates? still further. The remaining skin samples were received from spontaneous abortions (often? IUD) and stillbirths. For skin specimens from 3 these sources, postmortem tissue macerationo may be the most important factor. Selection of 3 other fetal (for example, muscle) or extra-fetalo specimens (for example, placental cord insertion site) instead of skin specimens shouldo result in a dramatic improvement in overall success rates. This approach might be particu- - o larly valuable for stillbirths, where maceration $\tilde{0}$ has been associated with a higher rate of chro- $-\widetilde{\omega}$ mosome abnormality $(10 \%)$ than unmacerated stillbirths $(3.5 \%) .^{5}$

Culturing cord or cardiac blood samples may also provide a useful backup. If blood cul-ture is successful then tissue culture need not ${ }_{0}^{-}$ be continued. The cytogenetic results from $\overrightarrow{0}$ POC and placental biopsy specimens showed that maternal cell contamination was a serious problem irrespective of the tissue cultured. Identification and selection of fetal material foro culture should always be attempted from POC to minimise this problem but in the majority ofo cases fetal tissue will not be available. Where $\mathrm{a}$ normal female chromosome complement is reported for such specimens, the need for a caveat on cytogenetic reports alerting the referring clinician to the possibility of a misleading result should be recognised. These results emphasise that for recurrent miscar- 
riages the most appropriate cytogenetic investigation is to analyse the chromosome complements of both parents from blood samples to exclude structural rearrangements. Studies on spontaneous abortions may still be justified following in vitro fertilisation assisted pregnancies $^{11}$ and those from parents with a known chromosome abnormality.

With an informed approach to sample selection and processing, the cytogenetic investigation of tissue biopsy specimens provides a valuable diagnostic service. This survey has highlighted areas where improvements can be made and provided evidence for a strategy for their achievement.

The ACC Solid Tissue Working Party Report $^{7}$ made five recommendations for improving the quality of the service provided:

- Laboratories should have a set of guidelines for the acceptance, transport and culture of specimens sent to the laboratory for dissemination to referring clinicians and other medical and nursing staff.

- For confirmation of cytogenetic prenatal diagnosis and other appropriate cases where a cytogenetic abnormality is suspected, it would be advisable to culture cardiac or cord blood when available together with solid tissue specimens.

- Skin samples should be avoided from IUD and macerated stillbirths. Skin samples should be transported to the laboratory in a suitable transport medium.

- Maternal cell contamination is a serious problem, particularly from POC, limiting the potential value of cytogenetic analysis of these specimens. A normal female result $(46, \mathrm{XX})$ should be treated with suspicion. An appropriately qualified cytogenetic report should be given for such samples.

- The quality of cytogenetic findings from solid tissue samples may fall below the standard achievable from blood samples. Where a fetus is dysmorphic or where recurrent miscarriages have occurred, analysis of parental blood should be performed to exclude a balanced chromosomal rearrangement in one or other parent.

The authors thank the cytogeneticists and support staff in individual laboratories who contributed their time and effort to data collection for the ACC survey. We would also like to thank Mrs Joyce Crossley for her assistance in the preparation of this Joyce Cross

Laboratories contributing to this survey: Medical Genetics Laboratories contributing to this survey: Medical Genetics
Laboratories, Aberdeen Royal Hospital, Aberdeen AB9 2ZD West Midlands Regional Genetic Services, Birmingham Heart- lands Hospital, Birmingham B9 5SS; West Midlands Regional Genetic Services, Birmingham Maternity Hospital, Birmingham B15 2TG; SW Regional Cytogenetics Centre, Southmead Hospital, Bristol BS10 5NB; Regional Cytogenetics Unit, Addenbrookes Hospital, Cambridge CB2 2QQ; Cytogenetics Unit for Wales, University Hospital of Wales, Cardiff CF4 4XW; Genetics Department, St Richard's Hospital, Chichester, West Sussex; Cytogenetics Laboratory, Queen's Hospital, Croydon, Surrey CR9 2PQ; Cytogenetics Laboratory, Ninewells Hospital, Dundee DD1 9SY; Lothian Area Cytogenetics LoboHospital, Dund Dur, Rdinburgh ED9 1LF Guncan Guthrie Institute of Medical Genetics, Yorkhill, Park Hospital, Harrow HAl 3UJ; Cytogenetics Department, Park Hospital, Harrow HAl 3UJ; Cytogenetics Department,
Royal Northern Infirmary, Inverness IV2 3UJ; Yorkshire Regional Cytogenetics Unit, St James's University Hospital, Leeds LS9 7TF; Cytogenetics Department, Leicester Genetics Centre, Leicester Royal Infirmary, Leicester LE1 5WW; Mersey Regional Cytogenetics Unit, Royal Liverpool University Hospital, Liverpool L7 8XP; SE Thames Regional Genetics Centre, Guy's Hospital Medical School, London SE1 9RT; Cytonet Guy's Hospital Medical School, London SE1 gRT, CytogenetWo OXG; SW Thames Regional Cytogenetics Unit, St George's Hospital Medical School, London SW17 ORE; Cytogenetics
Unit, St Mary's Hospital Medical School, London W2 1PG; Unit, St Mary's Hospital Medical School, London W2 1PG;
Cytogenetic Services, Wimpole Street, London W1; NW Regional Cytogenetics Service, Royal Manchester Children's Hospital, Manchester M27 1HA; NW Regional Cytogenetics Unit, St Mary's Hospital, Manchester M13 0JH; Northern Regional Genetics Service, 19 Claremont Place, Newcastle upon Tyne NE2 4AA; Department of Cytogenetics, Norfolk ment of Cytogenetics, City Hospital, Nottingham NG5 1PB; Oxford Medical Genetics Laboratories, Churchill Hospital, Oxford Medical Genetics Laboratories, Churchill Hospital, Oxford OX3 7LJ; Wessex Regional Genetics Laboratory, Salis-
bury District Hospital, Salisbury SP2 7SX; Genetics Unit, bury District Hospital, Salisbury SP2 7SX; Genetics Unit,
Geoffrey Schofield Laboratories, BNF plc, Sellafield, Seascale, Cumbria CA20 1PG; North Trent Cytogenetic Services, Centre for Human Genetics, Langhill, 117 Manchester Road, Sheffield S10 5DN.

1 Anonymous. Perinatal Pathology [editorial]. Lancet 1984; i: $431-2$.

2 Ellis PM, Bain AD. Cytogenetics and the evaluation of perinatal death. Lancet 1984;i:631-2.

3 Royal College of Obstetrics and Gynaecology. Report on fetal and perinatal pathology. Joint Working Party: RCOG and RCPath. London: Royal College of Obstetrics and Gynaecology, 1988.

4 Warburton D, Stein Z, Kline J, Susser M. Chromosome abnormalities in spontaneous abortions: data from the New York study. In: Porter IH, Hook EB, eds. Human embryonic and fetal death. New York: Academic Press, 1980:261-87.

5 Winter RM, Knowles SAS, Bieber FR, Baraitser M. Chapter 4. The malformed fetus and stillbirth: a diagnostic approach. In: Chromosome abnormalities in stillbirths, perinatal deaths and spontaneous abortions. Chichester: John Wiley and Sons, 1988:18-20

6 UK NEQAS. Report for Clinical Cytogenetics. 1993/94

7 ACC Working Party Report. Solid Tissue Culture in Cytogenetics. 1995.

8 Mueller RF, Sybert VP, Johnson J, Brown ZA, Chen W-J. Evaluation of a protocol for post-mortem examination of stillbirths. N Engl f Med 1983;309:586-90.

9 Clayton-Smith J, Farndon PA, McKeown C, Donnai D. Examination of fetuses after induced abortion for fetal abnormality. BM7 1990;300:295-7.

10 Warburton D, Byrne J, Canki N. Chromosome anomalies and prenatal development: An atlas. Oxford monographs on medical genetics. No. 21. Oxford: Oxford University Press, 1991.

11 In't Veld PA, Van Opstal D, Van Den Berg O, Van Oouen M, Brandenburg $\mathrm{H}$, Lupers $\mathrm{L}$, et al. Increased incidence of cytogenetic abnormalities in chorionic villus samples from pregnancies established by in vitro fertilisation and pregnancies established by in vitro fertilisation and
embryo transfer (IVF-ET). Prenat Diagn 1995;15:975-80. 